\title{
Cranial nerve palsies in spontaneous carotid artery dissection
}

\author{
Matthias Sturzenegger, P Huber
}

\begin{abstract}
Two patients had isolated unilateral cranial nerve palsies due to spontaneous internal carotid artery (ICA) dissection without ischaemic cerebral involvement. One had acute glossopharyngeal and vagal, the other isolated hypoglossal nerve palsy. Reviewing all reported cases of angiographically confirmed ICA dissection in the literature, 36 additional cases with unequivocal ipsilateral cranial nerve palsies were analysed. While an isolated palsy of the IXth and Xth has not been reported previously, palsies of the XIIth nerve or the IXth to XIIth nerves were most frequently found. In these patients, lower cranial nerve palsies are probably the result of compression by an enlarging ICA due to mural haematoma. Symptoms and signs indicative of carotid dissection were concurrently present only in some reported cases. This raises the question of unrecognised carotid dissection as a cause of isolated cranial nerve palsies. When the dissection occurs in the subadventitial layer without relevant narrowing of the arterial lumen and when an aneurysm is thrombosed, angiography does not reliably yield the diagnosis. Therefore, carotid dissection might have been underestimated as a cause of isolated lower cranial nerve palsies before the advent of MRI. MRI demonstrates directly the extension of the wall haematoma in the axial and longitudinal planes. Some arteriopathies such as fibromuscular dysplasia and tortuosity make a vessel predisposed to dissection.
\end{abstract}

$(F$ Neurol Neurosurg Psychiatry 1993;56:1191-1199)

Department of Neurology, University of Berne, Inselspital, CH-3010 Berne, Switzerland M Sturzenegger

Department of Neuroradiology, University of Berne, Inselspital, CH-3010 Berne, Switzerland P Huber

Correspondence to: M Sturzenegger, $M D$ Department of Neurology, University of Berne, Inselspital, $\mathrm{CH}-3010$ Berne, Switzerland.

Received 2 November 1992 in revised form

31 December 1992

Accepted 14 January 1993 internal carotid artery (ICA) dissection is highly variable. Sudden, intense unilateral pain in the neck and face, ipsilateral oculosympathetic paresis, and transient monocular blindness (amaurosis fugax) associated with a contralateral transient ischaemic attack or stroke form the typical presenting triad suggesting extracranial carotid dissection..$^{123}$ Lower cranial nerve palsies seem to be a rare finding, with the hypoglossal nerve being the most frequently affected $(5 \%)^{4}$ : However, when ICA dissection occurs without CNS involvement, it is not readily recognised as the cause of a cranial nerve palsy. Some of the reported "idiopathic" jugular foramen (Vernet) and similar syndromes (Villaret, Collet Siccard) in the older literature might well have been caused by spontaneous carotid dissection. ${ }^{5}$ In those times ICA dissection as a cause of cranial nerve palsy was poorly known, angiography quite risky, and ultrasound and MRI not available. Out of 31 consecutive patients with ICA dissection diagnosed at our department within four years, two presented with cranial nerve palsies without cerebral involvement.

\section{Case reports}

PATIENT 1

A 42-year-old man had been in excellent health. He had no vascular risk factors. After strenuous activity (cutting wood) in military service he suddenly felt pain in the right upper jaw which later extended to the ear and the whole right side of his face. He suffered an episode of hazy vision on the right eye lasting about five minutes. The following morning pain had almost disappeared, but he had difficulty swallowing and could not drink properly. His voice had a nasal sound. Otherwise he felt well. In the hospital, three days after first symptoms had occurred, his voice was severely hoarse, almost aphonic, and nasal. On examination he had a drooping right palate arc. On phonation the palate as well as the dorsal wall of the pharynx deviated to the left. Sensation to touch of the right posterior pharyngeal wall was reduced and the gag reflex could not be elicited on the right side. No other signs were found. Chest $x$-ray, ECG, and routine blood laboratory tests were normal. Initially brainstem infarction was suspected and a posterior fossa CT scan was performed which was normal. Because of the right sided facial pain and the initial episode of presumed right amaurosis fugax, right ICA dissection was suspected.

Duplex sonographic examination of the

The clinical presentation of spontaneous 
lation with heparin sodium was started. The following day, a right common carotid arteriogram was performed which also revealed the ICA tortuosity. There were irregularities of the vessel wall about $3 \mathrm{~cm}$ distal of the bifurcation and extending cranially beyond the coiling. Equivocal slight stenosis on the anteroposterior projections was visible (fig 1). In addition, a pouch with trapped contrast media showed up on the late lateral views (fig 1 a2 and 1 a3) which is a quite distinct sign of dissection. These findings confirmed the suspected diagnosis of ICA dissection. They could, however, not explain the glossopharyngeal and vagal nerve palsy.

MR images of the upper cervical region performed eight days after the first symptoms
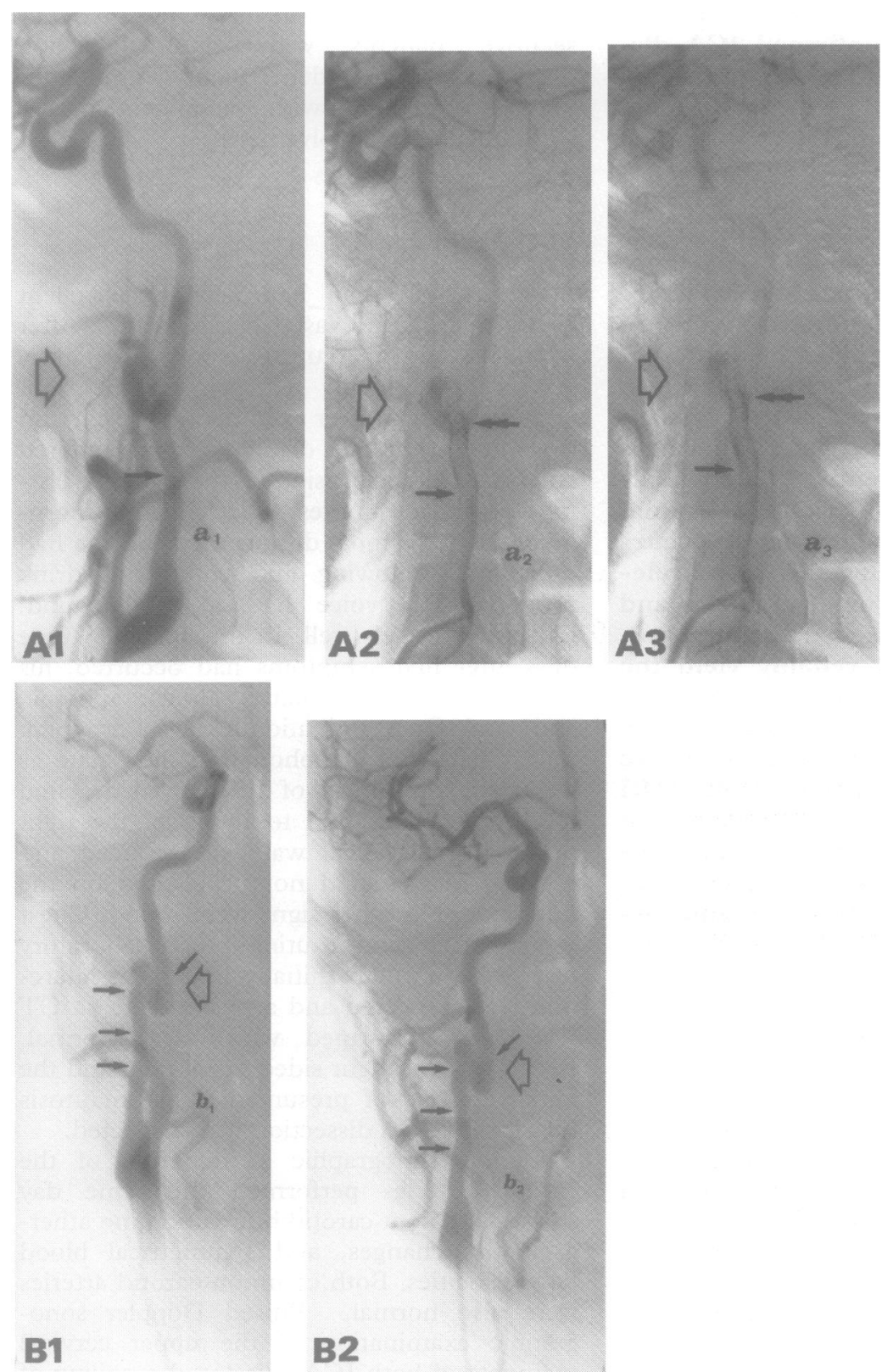

Figure 1 (Patient 1) Right common carotid arteriogram (a1 to a3 sequential lateral views, $b 1$ and b2 sequential anteroposterior projections). Lateral views demonstrate only minimal wall irregularities (arrows) without recognisable stenosis. On late images ( $a 2$ and a3) a pouch can be seen wherein contrast material is trapped (double arrow) situated in the ascending loop of a carotid artery loop (open arrow). Wall irregularities are much more marked on anteroposterior projections (small arrows in b1 and b2), starting about $2 \mathrm{~cm}$ distal to carotid bifurcation and extending beyond the artery loop (open arrow). There seems to be only slight stenosis in this segment of ICA. yielded the explanation. A large ICA mural haematoma was demonstrated as a hyperintense signal on the sagittal and axial sections of the T1- and T2-weighted and proton density spin echo sequences (fig 2). It extended from beneath the coiling up to the petrosal carotid canal. In the axial plane, a large subadventitial extension of the haematoma was demonstrated with expansion of the vessel wall in the carotid space. This led to displacement of the parapharyngeal space (fig 2 bl and 2 b2) where the glossopharyngeal nerve crosses the ICA medially leading from the jugular foramen to the root of the tongue. In this region the $\mathrm{Xth}$ cranial nerve is also in close contact with the ICA (fig 3). Cranial MRI was normal.

After one week of heparin treatment, oral anticoagulation with a coumarin was started. No visual or TIA-like symptoms occurred. Six weeks after admission, hoarseness and nasal voice were still present, but swallowing was possible again. Pharyngeal sensation was normal on both sides, no palate droop was found any more and pharyngeal wall shift on phonation was only minimal. Doppler sonography still showed a higher blood flow velocity on the right side. A second MRI scan eight weeks after admission showed complete resolution of the mural haematoma. Anticoagulants were continued and after a total of 11 weeks all symptoms and signs had cleared. A persistent slight asymmetry of blood flow velocities at Doppler examination was considered to be due to possible slight residual stenosis. Coumarins were stopped and aspirin started.

\section{PATIENT 2}

A 45-year-old man had untreated mild arterial hypertension for several years. During the past two years he suffered from intermittent slight nuchal pain. Two days before admission nuchal pain intensified but did not change its well known quality. There was no special event and no trauma. On the day of admission he noticed difficulty with articulation, a heavy tongue, and problems to eat. Slightly slurred speech was noted by his wife. Brainstem infarction was suspected and a CT scan performed which was normal. On admission he clearly stated that he could not properly move the food with his tongue, while oral sensibility, chewing, and swallowing were not disturbed. Examination showed moderate left hypoglossal palsy with tongue deviation to the left when thrusting it out and deviation to the right when phonating. No other signs were found. Chest and cervical spine $x$ ray, electrocardiogram, and routine blood laboratory tests were normal.

Doppler and Duplex sonographic examination of the cervical carotid and vertebral arteries and transcranial Doppler sonography on the day of admission were normal. Repeat ultrasound study the following day revealed occlusion of left ICA with typical signs indicating dissection. ${ }^{6}$ Transcranial Doppler examination showed good collateral supply from the right carotid and from the verte- 

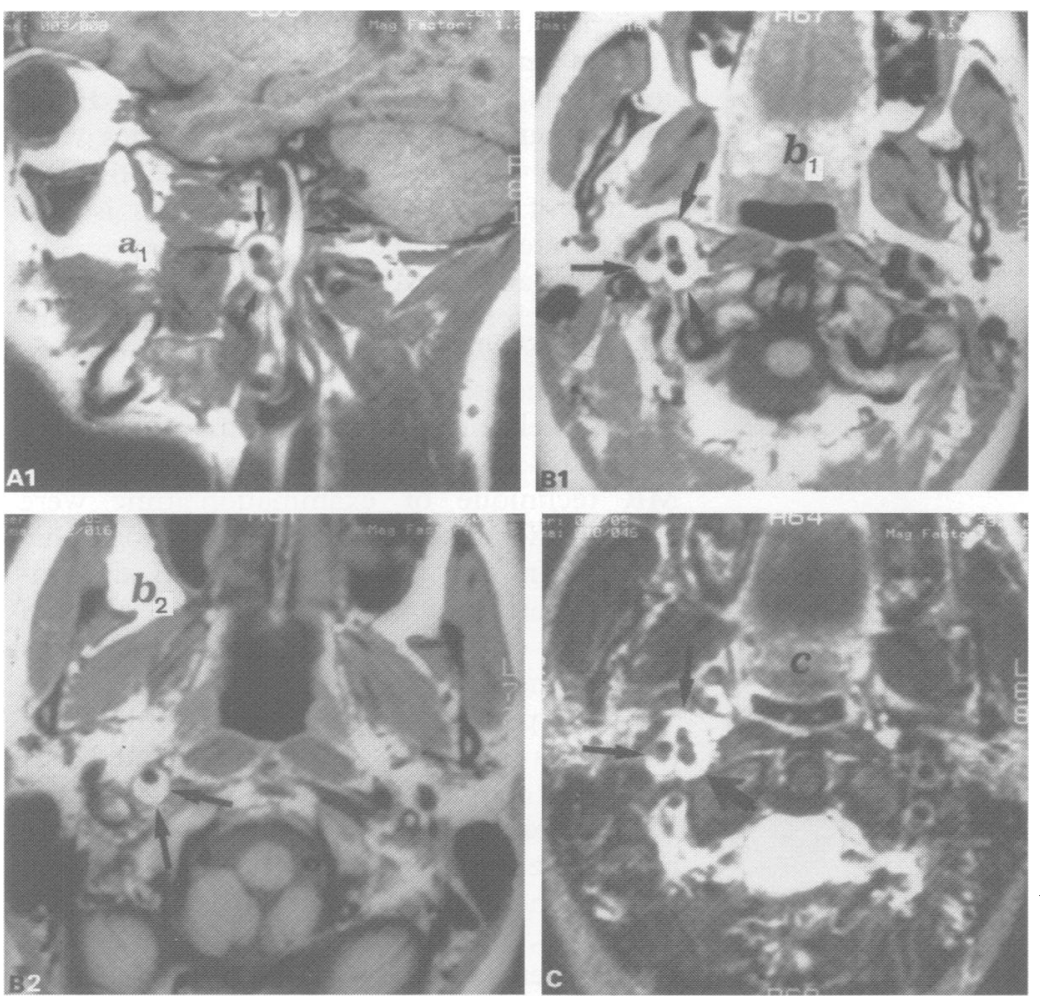

Figure 2 (Patient 1) MR images at 1.5 tesla. The sagittal right paramedian $T 1$ weighted $(T R=400 \mathrm{~ms}, T E=18 \mathrm{~ms}$ ) section (a1) demonstrates mural haematoma "looping" along the ICA coiling as hyperintense signal (arrows). There is only minimal stenosis of the vessel lumen represented by the adjacent low signal ("flow void"). The T1 weighted $(T R=500 \mathrm{~ms}, T E=16 \mathrm{~ms})$ adjacent axial sections at the atlas level (b1 and b2) demonstrate large expansion of ICA vessel wall by mural haematoma. The hyperintense signal surrounds in a semilunar shaped way all three coils of the loop (arrows in b1). Also the contralateral left ICA shows a coiling (three sectioned lumina (flow voids)) without mural haematoma (see b1). Note the large posterior expansion of the mural haematoma (arrows) into the region where the glossopharyngeal nerve passes on image b2. The same, trefoil leaf-shaped, hyperintense signal is demonstrated on $T 2$ weighted ( $T R=3,000 \mathrm{~ms}, T E=90 \mathrm{~ms}$ ) axial sections (c) at the atlas level (arrows) identifying the underlying pathology as blood.

Figure 3 Drawing of an anatomical axial section through the neck at the level of the first cervical vertebral body (atlas). The close relationship between the ICA and the IXth, Xth XIth and XIIth cranial nerves is highlighted in the magnified cutting. (1) nasal cavity; (2) maxillary sinus; (3) facial muscles; (4) jaw muscles; (5) neck muscles; (6) atlas body; (7) parotid gland; (8) parapharyngeal space. (Compare with axial $M R$ image: fig 2 b1).

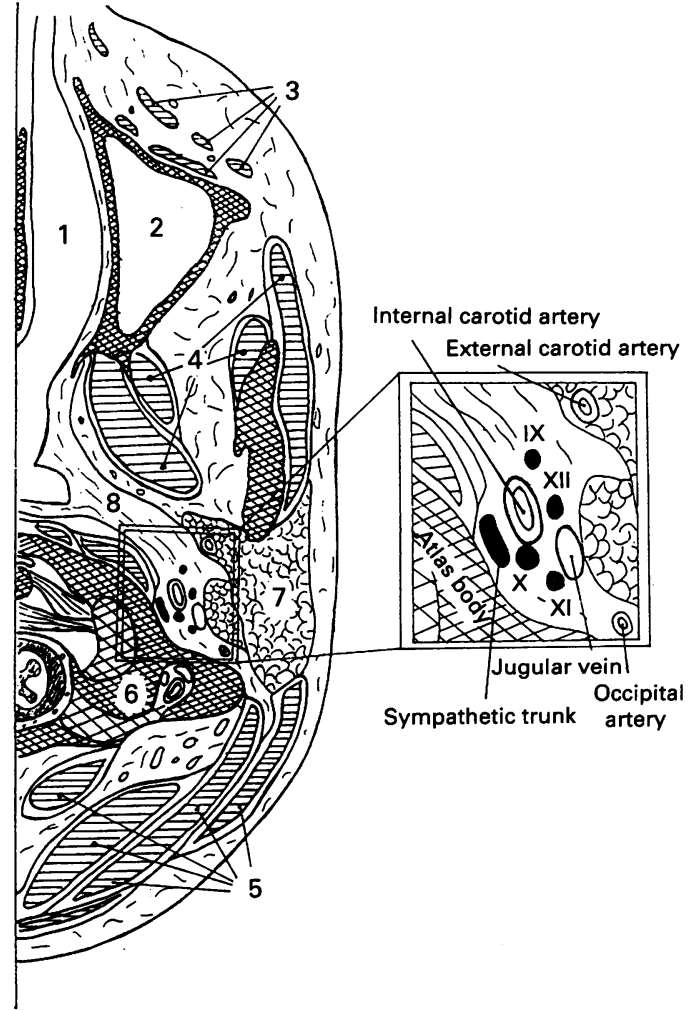

brobasilar system across the circle of Willis. $M R$ images of the upper cervical region were performed two days after the first symptoms. They showed a mural haematoma in the prepetrosal left ICA segment with severely narrowed lumen (flow void). Caudal to it there was an isodense mass adjacent to the artery, probably representing an aneurysm (fig 4). Three sectioned lumina (flow void) on both sides indicated bilateral coiling. There were no signal changes in the brain, brainstem, or cerebellum. Bilateral carotid angiography was performed three days after the first symptoms. It showed bilateral coiling before the ICAs entered the petrosal canal. On the left side contrast filling was markedly delayed and a saccular aneurysm attached to the coiling filled. The segment immediately distal to the coiling was severely stenosed (fig 5). On the day of admission heparin treatment was begun and seven days later changed to oral anticoagulation. Control ultrasound examination seven days later showed partial resolution of the occlusion with a now present, though diminished flow signal in the left ICA. Hypoglossal palsy was still slightly present but subjective discomfort was minimal.

\section{Review of the literature}

All reported series and cases of spontaneous ICA dissection were reviewed looking for unequivocally documented symptoms and signs of cranial nerve involvement. Swallowing difficulty alone was not considered to indicate IXth or Xth nerve dysfunction because local expansion of the aneurysm towards the pharynx might be the cause. ${ }^{7}$ Unilateral "scalp tenderness", a frequently encountered symptom in some series, ${ }^{8}$ was not considered to indicate trigeminal nerve involvement unless there was a clear sensory deficit reported. "Dysgeusia" (unpleasant, strange taste) does, in our opinion, indicate facial or glossopharyngeal nerve dysfunction. As Maitland did, ${ }^{9}$ we suspect a compression of the IXth rather than of the VIIth nerve or of the chorda tympani to be the cause. ${ }^{810}$ Detailed testing of taste, which should allow a differentiation, was not reported in these cases. If a nerve compression by the expanding wall haematoma (pseudoaneurysm) is the pathogenetic mechanism, the IXth nerve is more at risk. If, however, interruption of the nerve's blood supply is the working mechanism, the IXth and VIIth may be affected equally. Finally, isolated tinnitus was not considered a sign of VIIIth nerve dysfunction.

Only cases in whom the diagnosis had been supported by angiography showing a typical picture were considered. ${ }^{1381112}$

\section{Results}

Thirty-six patients reported under the heading of carotid dissection with signs of ipsilateral cranial nerve palsies were found in the literature and analysed together with our two patients (table 1). ${ }^{2891012-31}$ In 35, the age and sex were given: the average age was 44 years, 

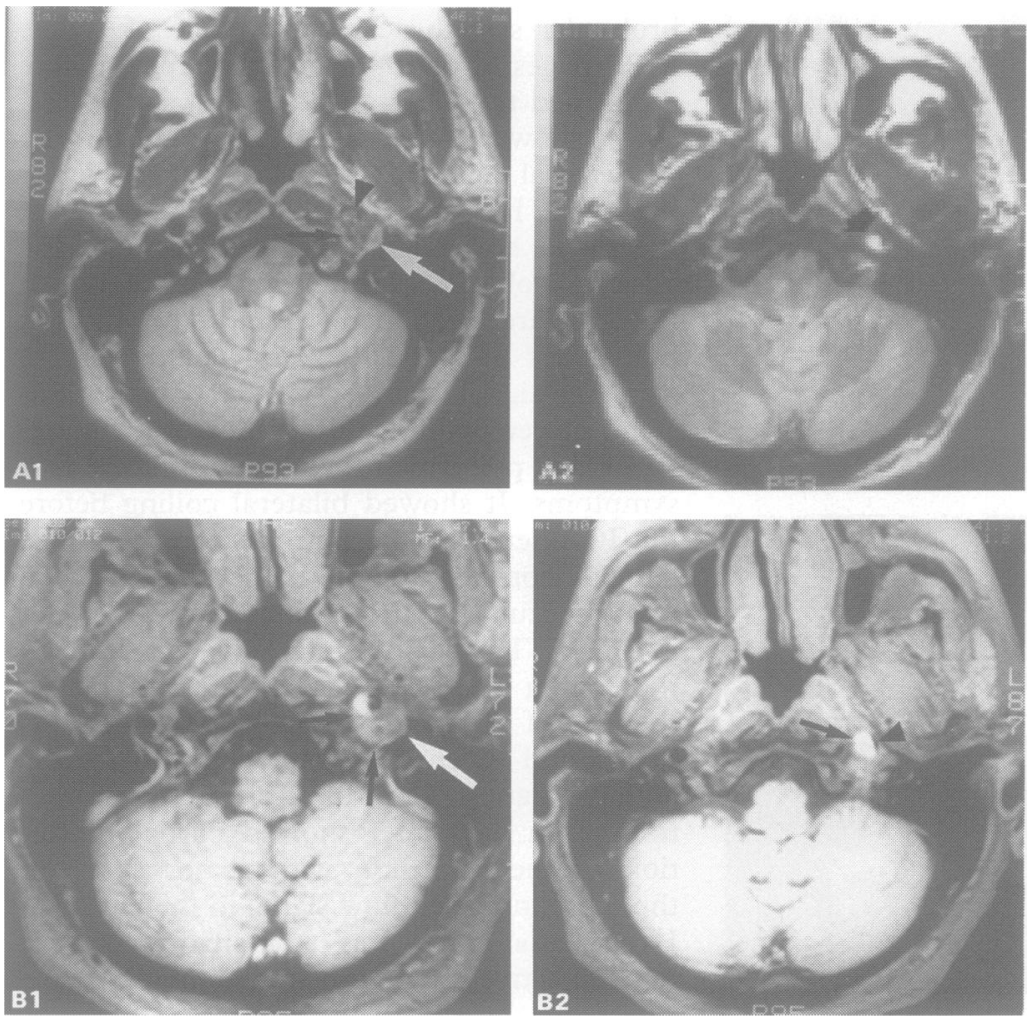

Figure 4 (Patient 2) MR images at 1.5 tesla. The proton density weighted $(T R=2740$ $m s, T E=30 \mathrm{~ms}$ ) contiguous axial sections at the level of the skull base (a1 and a2) demonstrate narrow lumen (flow void) of left ICA (arrowhead in a1) and a surrounding mass with mixed iso and hyperintense signal (arrows in a1). A little more cranially a hyperintense signal adjacent to the flow void signal indicates mural haematoma (arrow in a2). These signal changes are even better visualised on T1-weighted (TR $=800 \mathrm{~ms}$, $T E=11 \mathrm{~ms}$ ) axial sections with fat suppression technique (b1 and b2): The mass asymmetrically surrounding the narrowed vessel lumen (arrows in b1) represents the aneurysm. The slit-like residual lumen (arrowhead in b2) is compressed by the mural haematoma shown as hyperintense signal (arrow in b2). minority of the reported cases had documented cerebral four vessel angiography and comments concerning the presence of FMD and tortousity in other cranial arteries were frequently lacking. Therefore, the relative frequency of these vascular alterations is certainly underestimated.

In 16 patients MRI scans were performed, 14 of which had a mural haematoma demonstrated. In two patients the MRI showed no hyperintense signal. In one of these the delay was 8 weeks and the haematoma might have resolved. ${ }^{28}$ In the other patient no details on MR technique or examination time were given in the presence of a typical angiographic result. ${ }^{10}$ In our two patients MRI demonstrated tortuosity (fig 2 b1) and also an aneurysm (fig 4 bl) in addition to the mural haematoma.

In 27 patients an ipsilateral XIIth nerve palsy was reported, 10 times isolated, six times in conjunction with IXth, Xth, and XIth nerve palsies, four times with $X$ th nerve palsy, five times with IXth and Xth nerve palsies, once with XIth nerve palsy, and once with IXth, Xth, VIIth, and Vth nerve palsies. Five patients had dysgeusia, three isolated, one in conjunction with Vth, and one with VIth nerve palsy. Among seven patients with a Vth nerve palsy, it was isolated in four. All patients with Vth, VIth, or IIIrd nerve palsy had an extension of the dissection up to the cavernous segment. The compiled frequency of the affected cranial nerves in the 38 cases was as follows (table 1): XIIth: 27 times; IXth (including the five patients with dysgeusia): 18 times; Xth: 17 times; XIth: 7 times; Vth: 7 times; VIIth/VIth/IIIrd: once each. In 20 patients $(53 \%)$ an ipsilateral oculosympathetic paresis (Horner's syndrome) was observed.

In 13 patients information about outcome of cranial nerve palsies was given: eight patients had recovered after three weeks to two years, usually within two to four months; five patients had persistent palsies after three to 10 months and, hence, some might well have recovered later on.

Ten patients (26\%) had ischaemic symptoms. Six had a transient and two a persistent hemiparesis contralateral to the dissection, and two had an ipsilateral amaurosis fugax.

had a saccular aneurysm (fig 5); one ha double lumen; and in one patient no details on the "aneurysm" were available. In three patients detailed angiographic results were not given. In 35 patients the site of the dissection could be located: the prepetrosal segment was involved in all, 11 showed extension of the dissection to the (lower) cervical segment, 11 to the intrapetrosal, and eight to the cavernous segment. In three patients this information was not provided. In 26 patients data about tortuosity of the ICA were given: 10 patients (38\%) had some degree of tortuosity, four had kinking, three coiling, and three moderate tortuosity. Four patients had documented findings suggestive of fibromuscular dysplasia (FMD). Tortuosity as well as the signs of FMD may be masked by the dissection itself. Only a

\section{Discussion}

Peripheral cranial nerve palsy caused by ICA dissection is only rarely observed. In the large reported series totalling 356 patients with ICA dissection, no cranial nerve palsies were described. ${ }^{232-43}$ Most of these patients with angiographically confirmed ICA dissection were presenting with cerebral ischaemic signs and symptoms. On the other hand, only 8 (21\%) of 38 patients presenting with cranial nerve palsies due to ICA dissection collected from the literature (table 1) showed cerebral ischaemic involvement.

This discrepancy may be due to not noticing ipsilateral cranial nerve palsies in the presence of signs of contralateral stroke. It might 

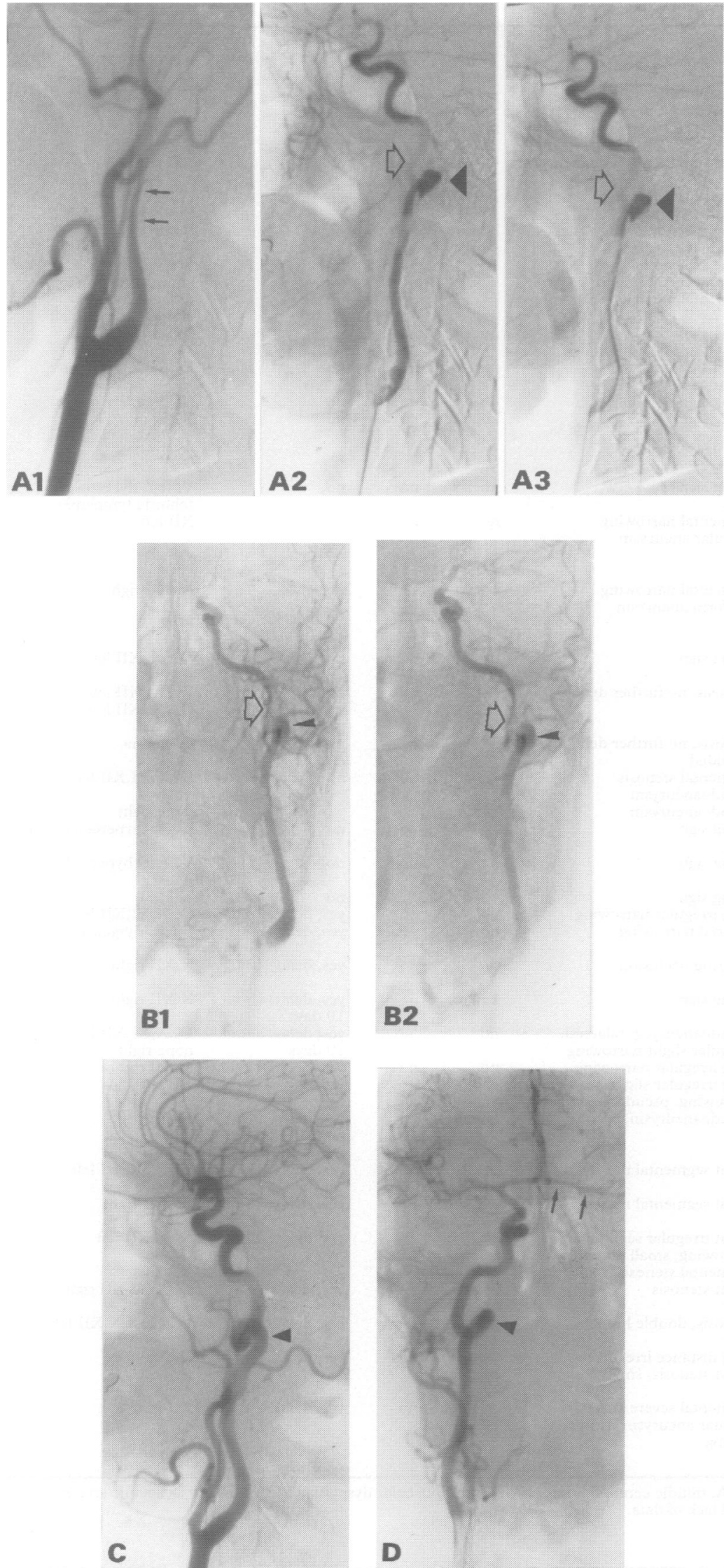

Figure 5 (Patient 2) Bilateral common carotid arteriogram (a1 to a3: sequential lateral views, $b 1$ and b2: sequential anteroposterior projections of the left side; $c$ and d lateral and anteroposterior views respectively of the right side). Left side: Lateral views demonstrate delayed ICA filling (a1) simulating "string sign" in the early images (arrows in a1), saccular aneurysm attached to coiling (arrowhead in $a 2$ and $a 3$,) and poor contrast of the segment distal to the aneurysm (open arrow in a2 and a3) because of stenosis (see b); contrast material is trapped in the aneurysm (a3). Anteroposterior views demonstrate aneurysm attached to the coiling (arrowhead in b1 and b2) and high grade stenosis immediately distal to the coiling (open arrow in b1 and b2). Right side: Lateral (c) and anteroposterior (d) view show prepetrosal ICA coiling (arrowhead). Collateral blood supply from right ICA to left MCA across circle of Willis (arrows in d). also indicate that ICA dissection as a cause of lower cranial nerve palsies is not readily recognised. In a recent review of 32 patients with XIIth nerve palsy, ${ }^{44}$ carotid dissection was considered to be the cause in only one patient, and this was a traumatic dissection. Unfortunately, no details on the diagnostic examination of these patients are given. Therefore, the question remains, whether some of the reported patients with so called traumatic XIIth nerve palsies or some of those attributed to brainstem ischaemia ${ }^{25}$ in reality had a carotid dissection causing the nerve palsy. In our own series of 31 patients with ICA dissection, the two patients reported here $(6 \%)$ presented with isolated cranial nerve palsies. In retrospect, we recall another two patients who presented with isolated XIIth nerve palsy and ipsilateral neck pain. CT scan did not support the suspected diagnosis of a cervical tumour or infection. This was several years ago when ICA dissection was not considered as a possible cause and hence no further investigations were performed.

However, the relatively frequent observation of isolated cranial nerve palsies without central involvement ( $79 \%$ ) as opposed to the rare observation of cranial nerve palsies in ICA dissection patients with cerebral ischaemic symptoms could indicate that these two groups have a different pathogenesis. It is, for instance, conceivable that the former had subadventitial rather than subintimal dissections, since the subadventitial dissection is less likely to obstruct the vessel lumen and would rather extend outwardly. Several facts from our analysis support such a hypothesis: (1) the higher prevalence of men in the ICA dissection patients with cranial nerve palsies $(86 \%)$ as opposed to the general ICA dissection population $(51 \%),{ }^{4}(2)$ like in traumatic ICA dissection, ${ }^{32}$ there is a high prevalence of aneurysms in spontaneous ICA dissection patients with cranial nerve palsies (49\%), while aneurysms in ICA dissection patients with hemispheric signs are less frequent $(10-33 \%)^{31133}$; (3) the higher prevalence of extreme vessel tortuosity in the ICA dissection patients with cranial nerve palsies $(27 \%)$ compared with the general population $(3-12 \%) .{ }^{45}$ Tortuosity may indicate a structure wall anomaly making the vessel predisposed to external mechanical injury. Tortuosity also does alter flow dynamics which may cause sheer injury to the vascular wall again making the affected vessel predisposed to dissection. Could more frequently occurring trivial and unreported traumas of a physically more active male population be favouring subadventitial dissection in the presence of a predisposing arteriopathy?

In the case of subadventitial dissection, muscular medial layer may impede narrowing of the lumen and the mural haematoma may considerably expand the circumference of the vessels (figs $2 \mathrm{~b}$ and $4 \mathrm{~b}$ ). The close topographical relationship of the most frequently involved XIIth, IXth, and Xth nerves with the carotid artery in the upper cervical parapha- 
Table 1 Patients with spontaneous ICA dissection and cranial nerve palsies

\begin{tabular}{|c|c|c|c|c|c|c|c|c|}
\hline Reference & Age/Sex & Side & $\begin{array}{l}\text { Site of ICA } \\
\text { dissection }\end{array}$ & Angiography & Tortuosity & $F M D$ & $M R I$ (delay) & $\begin{array}{l}\text { Cranial nerve } \\
\text { palsies }\end{array}$ \\
\hline Kramer $^{14}$ & $41 / F$ & left & prepetrosal & $\begin{array}{l}\text { segmental narrowing, } \\
\text { aneurysm prepetrosal }\end{array}$ & no & yes & no & IX, X(?), XII left \\
\hline Gros $^{15}$ & $38 / \mathrm{M}$ & left & prepetrosal & fusiform aneurysm & no & no & no & XII left \\
\hline Labauge $^{13}$ & $38 / \mathrm{M}$ & left & prepetrosal & slight stenosis, pseudoaneurysm & $?$ & $?$ & no & XII left \\
\hline \multirow[t]{2}{*}{ Cohen $^{16}$} & $31 / \mathrm{F}$ & left & $\begin{array}{l}\text { pre and intrapetrosal, } \\
\text { cavernous (?) }\end{array}$ & $\begin{array}{l}\text { segmental narrowing } \\
\text { pseudoaneurysm }\end{array}$ & $?$ & yes & no & $V(1+2)$ left \\
\hline & $38 / \mathbf{M}$ & left & $\begin{array}{l}\text { pre and intrapetrosal } \\
\text { cavernous (?) }\end{array}$ & $\begin{array}{l}\text { segmental narrowing } \\
\text { pseudoaneurysm }\end{array}$ & $?$ & yes & no & V left \\
\hline \multirow[t]{2}{*}{ Fisher $^{8}$} & $45 / M$ & left & cervical + prepetrosal & $\begin{array}{l}\text { string sign up to } \\
\text { petrosal canal, pouch }\end{array}$ & $?$ & $?$ & no & $\begin{array}{l}\text { dysgeusia } \\
\text { chorda tympani left? }\end{array}$ \\
\hline & $53 / \mathrm{M}$ & left & prepetrosal & segmental narrowing & $?$ & $?$ & no & $\begin{array}{l}\text { dysgeusia } \\
\text { chorda tympani left ? }\end{array}$ \\
\hline Barbizet $^{17}$ & $42 / \mathrm{M}$ & right & $\begin{array}{l}\text { cervical, prepetrosal, } \\
\text { intrapetrosal, cavernous }\end{array}$ & $\begin{array}{l}\text { string sign } \\
\text { emboli in MCA branches }\end{array}$ & no & no & no & III and V right \\
\hline Bradac $^{18}$ & $58 / \mathrm{M}$ & left & prepetrosal & $\begin{array}{l}\text { string sign, saccular } \\
\text { aneurysm }\end{array}$ & no & no & no & IX, X, XI, XII left \\
\hline Goodman $^{19}$ & $\begin{array}{l}41 / M \\
59 / M\end{array}$ & $\begin{array}{l}\text { left } \\
\text { right }\end{array}$ & $\begin{array}{l}\text { prepetrosal } \\
\text { prepetrosal }\end{array}$ & $\begin{array}{l}\text { string sign } \\
\text { string sign }\end{array}$ & $\begin{array}{l}\text { no } \\
\text { kinking }\end{array}$ & $\begin{array}{l}\text { no } \\
\text { no }\end{array}$ & $\begin{array}{l}\text { no } \\
\text { no }\end{array}$ & $\begin{array}{l}\text { XII left } \\
\text { XII right }\end{array}$ \\
\hline Maitland ${ }^{9}$ & $37 / F$ & left & pre- and intrapetrosal, & string sign & no & no & no & VI left, dysgeusia \\
\hline \multirow[t]{3}{*}{ Hommel $^{20}$} & $55 / \mathrm{M}$ & left & $\begin{array}{l}\text { cavenous } \\
\text { prepetrosal }\end{array}$ & $\begin{array}{l}\text { segmental narrowing } \\
\text { saccular aneurysm }\end{array}$ & no & no & no & $\begin{array}{l}\text { (chordaa tympani?) } \\
\text { XII left }\end{array}$ \\
\hline & $54 / M$ & right & prepetrosal & $\begin{array}{l}\text { segmental narrowing } \\
\text { fusiform aneurysm }\end{array}$ & yes & no & no & $\mathrm{X}, \mathrm{XII}$ right \\
\hline & $44 / M$ & left & cervical, prepetrosal & string sign & no & no & no & IX, X, XII left \\
\hline Gauthier $^{12}$ & $?$ & $\begin{array}{l}\text { left } \\
\text { left }\end{array}$ & $?$ & $\begin{array}{l}\text { stenosis; no further details } \\
\text { ? }\end{array}$ & $?$ & $?$ & $\begin{array}{l}\text { no } \\
\text { no }\end{array}$ & $\begin{array}{l}\text { IX, X, XII left } \\
\text { IX, X, XII left }\end{array}$ \\
\hline Mokri $^{2}$ & $?$ & $?$ & $?$ & $\begin{array}{l}\text { stenosis, no further details } \\
\text { provided }\end{array}$ & $?$ & $?$ & no & dysgeusia \\
\hline Mokri2i & $47 / M$ & bilateral & prepatrosal left & $\begin{array}{l}\text { segmental stenosis } \\
\text { pseudoaneurysm }\end{array}$ & kinking & no & no & IX,X,XI,XII left \\
\hline \multirow[t]{2}{*}{ Benrabah $^{22}$} & $40 / \mathrm{M}$ & left & $\begin{array}{l}\text { prepetrosal right } \\
\text { cervical, prepetrosal, } \\
\text { cavernous }\end{array}$ & $\begin{array}{l}\text { pseudoaneurysm } \\
\text { string sign }\end{array}$ & $\begin{array}{l}\text { kinking } \\
\text { ? }\end{array}$ & no & no & $\begin{array}{l}\text { none right } \\
\text { V left (hypereresthesia) }\end{array}$ \\
\hline & $50 / \mathrm{M}$ & left & $\begin{array}{l}\text { cervical, prepetrosal, } \\
\text { cavernous }\end{array}$ & string sign & $?$ & no & no & V1 left (hyperesthesia) \\
\hline $\begin{array}{l}\text { Vighetto } \\
\text { Goldberg }^{24} \\
\text { Francis }^{10}\end{array}$ & $\begin{array}{l}48 / M \\
49 / M \\
46 / F\end{array}$ & $\begin{array}{l}\text { left } \\
\text { left } \\
\text { left }\end{array}$ & $\begin{array}{l}\text { prepetrosal } \\
\text { pre- and intrapetrosal } \\
\text { high cervical, intra- }\end{array}$ & $\begin{array}{l}\text { string sign } \\
\text { long irregular narrowing } \\
\text { tapered narrowing }\end{array}$ & $\begin{array}{l}\text { yes } \\
\text { no } \\
\text { no }\end{array}$ & $\begin{array}{l}? \\
\text { no } \\
\text { yes }\end{array}$ & $\begin{array}{l}\text { no } \\
\text { yes, delay: } 16 \text { days } \\
\text { yes, delay: ? }\end{array}$ & $\begin{array}{l}\text { XII left } \\
\text { IX,X,XI,XII left } \\
\text { V left, dysgeusia }\end{array}$ \\
\hline Hess $^{25}$ & $41 / M$ & right & $\begin{array}{l}\text { petrosal, cavernous } \\
\text { cervical, prepetrosal }\end{array}$ & tapering occlusion & no & no & yes, delay: 13 days & $\mathrm{X}, \mathrm{XII}$ right \\
\hline Lieschke $^{26}$ & $42 / M$ & right & prepetrosal & string sign & kinking & no & $\begin{array}{l}\text { yes, delay: about } \\
10 \text { days }\end{array}$ & $\mathrm{X}, \mathrm{XII}$ right \\
\hline Waespe ${ }^{27}$ & $41 / M$ & bilateral & prepetrosal bilateral & $\begin{array}{l}\text { pseudoaneurysm bilateral, } \\
\text { irregular slight narrowing }\end{array}$ & no & no & $\begin{array}{l}\text { yes; delay: about } \\
10 \text { days }\end{array}$ & $\begin{array}{l}\mathrm{IX}, \mathrm{X}, \mathrm{XI}, \mathrm{XII} \text { left } \\
\text { none right }\end{array}$ \\
\hline \multirow[t]{2}{*}{ Bradac $^{28}$} & $\begin{array}{l}28 / \mathrm{M} \\
41 / \mathrm{F}\end{array}$ & $\begin{array}{l}\text { right } \\
\text { left }\end{array}$ & $\begin{array}{l}\text { cervical, prepetrosal } \\
\text { cervical, prepetrosal }\end{array}$ & $\begin{array}{l}\text { long irregular narrowing } \\
\text { long irregular slight } \\
\text { narrowing, pseudoaneurysm }\end{array}$ & $\begin{array}{l}\text { no } \\
\text { coiling }\end{array}$ & $\begin{array}{l}\text { no } \\
\text { no }\end{array}$ & $\begin{array}{l}\text { yes, delay: } 10 \text { days } \\
\text { yes, delay: } 15 \text { days }\end{array}$ & $\begin{array}{l}\text { X,XII right } \\
\text { XII left }\end{array}$ \\
\hline & $53 / \mathrm{M}$ & left & prepetrosal & pseudoaneurysm, no stenosis & kinking ? & no & $\begin{array}{l}\text { yes, delay: } 8 \text { weeks } \\
\text { no hyperintense } \\
\text { signal }\end{array}$ & XII left \\
\hline \multirow[t]{3}{*}{ Dal Pozzo 29} & $58 / \mathrm{M}$ & left & prepetrosal & slight segmental narrowing & no & no & yes, delay: 19 days & IX,X,XI,XII left \\
\hline & $45 / M$ & right & prepetrosal & slight segmental narrowing & $?$ & $?$ & yes, delay: $\mathbf{4 0}$ days & $\mathrm{XI}, \mathrm{XII}$ right \\
\hline & $54 / M$ & left & $\begin{array}{l}\text { cervical, pre- and intra } \\
\text { petrosal }\end{array}$ & $\begin{array}{l}\text { slight irregular segmental } \\
\text { narrowing, small pouch }\end{array}$ & $?$ & $?$ & yes, delay: 27 days & IX,X,XII left \\
\hline \multirow[t]{2}{*}{$\begin{array}{l}\text { Vernay } \\
\text { Panisset }^{31}\end{array}$} & $\begin{array}{l}60 / M \\
36 / M\end{array}$ & $\begin{array}{l}\text { left } \\
\text { right }\end{array}$ & $\begin{array}{l}\text { prepetrosal } \\
\text { pre- and intrapetrosal }\end{array}$ & $\begin{array}{l}\text { segmental stenosis } \\
\text { slight stenosis }\end{array}$ & $\stackrel{\text { no }}{?}^{2}$ & $\begin{array}{l}\text { no } \\
?\end{array}$ & $\begin{array}{l}\text { yes delay: } 8 \text { weeks } \\
\text { yes, delay:? }\end{array}$ & $\begin{array}{l}\text { XII left } \\
\text { IX,X,XI,XII right }\end{array}$ \\
\hline & $53 / \mathrm{M}$ & left & $\begin{array}{l}\text { pre- and intrapetrosal, } \\
\text { cavernous? }\end{array}$ & stenosis, double lumen & yes & $?$ & yes, delay?: & V,VII,IX,X,XII left \\
\hline \multirow[t]{2}{*}{ Sturzenegger } & $42 / \mathrm{M}$ & right & cervical, prepetrosal & $\begin{array}{l}\text { long distance irregular wall, } \\
\text { slight stenosis, small pouch }\end{array}$ & $\begin{array}{l}\text { coiling } \\
\text { bilateral }\end{array}$ & no & yes, delay: 8 days & $\mathrm{IX}, \mathrm{X}$ right \\
\hline & $45 / M$ & left & pre- and intrapetrosal & $\begin{array}{l}\text { segmental severe stenosis } \\
\text { saccuar aneurysm within } \\
\text { coiling }\end{array}$ & $\begin{array}{l}\text { coiling } \\
\text { bilateral }\end{array}$ & no & yes, delay: 2 days & XII left \\
\hline
\end{tabular}

Year indicates year of publication; ICA, internal carotid artery; MCA, middle cerebral artery; FMD, fibromuscular dysplasia; TIA, transient ischaemic attack; ?, means that the respective criterion could not be analysed because of lack of data.

ryngeal space (fig 3) are a strong argument for a nerve compression by the expanded carotid wall as the underlying mechanism. In most cases the dissection begins 2 to $4 \mathrm{~cm}$ distal to the carotid bulb extending cranially and showing a maximal distension at the $\mathrm{C} 1$ or C2 vertebral level. At this point the IXth cranial nerve crosses the ICA laterally, the $\mathrm{Xth}$ lies posteriorly and medially, and the
XIIth crosses the ICA a little more caudally, in general at the C3 level. The fact that in patients with involvement of upper cranial nerves, dissection usually extended into the petrosal and cavernous segment (table 1 ) is another argument for a compression to be the causative mechanism. Nerve ischaemia due to compromised blood supply is a second possible mechanism. ${ }^{46} 47$ The IXth to XIIth nerves 


\begin{tabular}{|c|c|c|c|}
\hline $\begin{array}{l}\text { Horner's } \\
\text { syndrome }\end{array}$ & Pain & TLA/stroke & Special remarks \\
\hline yes left & ear, face, neck & no & dissection very likely \\
\hline no & temple left & $\begin{array}{l}\text { right arm }+ \text { face } \\
\text { transient }\end{array}$ & dissection probable \\
\hline no & face left & $\begin{array}{l}\text { paresis right arm } \\
\text { transient }\end{array}$ & persistent XII nerve palsy \\
\hline yes left & eye, cheek left & no & "Raeder's syndrome" \\
\hline yes left & temple left & no & "Raeder's syndrome" \\
\hline yes & face, eye left & $\begin{array}{l}\text { right arm }+ \text { face } \\
\text { transient }\end{array}$ & \\
\hline yes & face, eye left & no & \\
\hline yes & $\begin{array}{l}\text { neck, temple, } \\
\text { head right }\end{array}$ & $\begin{array}{l}\text { hemiplegia left } \\
\text { persistent }\end{array}$ & \\
\hline yes & neck left & no & \\
\hline yes & temple left & no & \\
\hline yes & neck right & $\begin{array}{l}\text { hemiparesis left } \\
\text { transient }\end{array}$ & \\
\hline no & $\begin{array}{l}\text { face, neck, } \\
\text { eye left }\end{array}$ & no & $\begin{array}{l}\text { recovery of VIth nerve palsy } \\
\text { within } 2 \text { months }\end{array}$ \\
\hline no & eye, temple left & no & $\begin{array}{l}\text { recovery of XIIth nerve palsy } \\
\text { within } 2 \text { months } \\
\text { control angiography after } 2 \text { months: } \\
\text { persistent aneurysm, no stenosis }\end{array}$ \\
\hline no & $\begin{array}{l}\text { temple, occipi- } \\
\text { tal right }\end{array}$ & no & $\begin{array}{l}\text { recovery of Xth nerve palsy within } \\
3 \text { days and of XIIth within } 6 \text { months } \\
\text { control angiography after } 8 \text { months; } \\
\text { persistent aneurysm, no stenosis }\end{array}$ \\
\hline no & $\begin{array}{l}\text { yaw, ear, face } \\
\text { left }\end{array}$ & $\begin{array}{l}\text { hemiplegia right } \\
\text { aphasia, persist }\end{array}$ & $\begin{array}{l}\text { XIIth nerve palsy persistent } \\
\text { control angiography after } 3 \text { months: } \\
\text { normal ICA left, MCA branch occlusion }\end{array}$ \\
\hline $\begin{array}{l}\text { yes } \\
\text { no }\end{array}$ & $\begin{array}{l}\text { face left } \\
\text { face, neck left }\end{array}$ & $\begin{array}{l}\text { no } \\
\text { right arm, } \\
\text { transient }\end{array}$ & $\begin{array}{l}\text { no details on angiography } \\
\text { no details on angiography }\end{array}$ \\
\hline$?$ & $?$ & $?$ & no further details provided \\
\hline yes left & occipital left & no & asymptomatic after $21 / 2 \mathrm{y}$ \\
\hline $\begin{array}{l}\text { no right } \\
\text { yes }\end{array}$ & $\begin{array}{l}\text { no } \\
\text { face, neck, eye } \\
\text { left }\end{array}$ & no & \\
\hline yes & face, eye left & no & \\
\hline $\begin{array}{l}\text { yes left } \\
\text { yes }\end{array}$ & $\begin{array}{l}\text { neck, temple left } \\
\text { face left }\end{array}$ & $\begin{array}{l}\text { no } \\
\text { no }\end{array}$ & \\
\hline yes & face, neck left & no & MRI = normal (?) delay not given \\
\hline no & orbital right & $\begin{array}{l}\text { hemiparesis left } \\
\text { transient }\end{array}$ & \\
\hline no & $\begin{array}{l}\text { temple, eye } \\
\text { right }\end{array}$ & no & \\
\hline no & neck, face left & no & $\begin{array}{l}\text { bilateral dissection, } \\
\text { right side asymptomatic }\end{array}$ \\
\hline $\begin{array}{l}\text { no } \\
\text { yes }\end{array}$ & $\begin{array}{l}\text { neck right } \\
\text { head }\end{array}$ & $\begin{array}{l}\text { no } \\
\text { amaurosis fugax }\end{array}$ & $\begin{array}{l}\text { XII paresis persistent after } 4 \text { months } \\
\text { XII paresis persistent after } 6 \text { months }\end{array}$ \\
\hline no & head, neck left & no & $\begin{array}{l}\text { XII paresis persistent after } 1 \text { year, } \\
\text { dissection not proved }\end{array}$ \\
\hline no & neck & no & $\begin{array}{l}\text { CT also positive. Follow up MRI after } 13 \\
\text { months; haematoma resolved. }\end{array}$ \\
\hline yes & neck right & no & $\begin{array}{l}\text { CT also positive. Follow up MRI after } 14 \\
\text { months: haematoma resolved }\end{array}$ \\
\hline yes & eye, front left & no & $\begin{array}{l}\text { CT negative. Follow up MRI after } 6 \\
\text { weeks: smaller still persistent haematoma. }\end{array}$ \\
\hline yes & occipital left & no & \\
\hline no & $\begin{array}{l}\text { occipital, eye } \\
\text { right }\end{array}$ & no & recovery within 2 months \\
\hline no & $\begin{array}{l}\text { occipital, neck } \\
\text { left }\end{array}$ & no & recovery within 6 months \\
\hline no & $\begin{array}{l}\text { yaw, ear, face } \\
\text { right }\end{array}$ & amaurosis fugax & $\begin{array}{l}\text { bilateral coiling at MRI. Follow up MRI } \\
\text { after } 7 \text { weeks: haematoma resolved. } \\
\text { clinical recovery within } 10 \text { weeks. }\end{array}$ \\
\hline \multirow{2}{*}{$\begin{array}{l}\text { no } \\
\text { andarteriog }\end{array}$} & nuchal & no & bilateral coiling (at MRI \\
\hline & & & $\begin{array}{l}\text { Partial resolution of stenosis after } 7 \text { days } \\
\text { (Ultrasound). Clinical recovery within } 3 \\
\text { weeks. }\end{array}$ \\
\hline
\end{tabular}

are supplied by the ascending pharyngeal artery and the Vth and VIIth by the middle meningeal artery. ${ }^{4647}$ Both arteries arise from the external carotid artery which may be directly affected by dissection or compressed by the expanding dissected ICA. There are few data supporting this pathogenesis. The distinction of these two mechanisms is, however, irrelevant for the diagnostic and thera- peutic management of the patients.

The proof of carotid artery dissection as the cause of cranial nerve palsies is a problem not yet solved. Angiography, considered as the standard by most authors, can detect a compromise of the vessel lumen only above a certain degree. The recognition of a low grade narrowing of the lumen is difficult, with considerable interobserver disagreement. ${ }^{48}$ In the case of a subintimally located dissection the mural haematoma will in the first place protrude the intima into the vessel lumen and produce a variable degree of stenosis up to occlusion. These cases are easily depicted by angiography. ${ }^{1381112}$ As the majority of ICA dissections seem to occur in the subintimal layer ${ }^{1}$ angiography is the diagnostic method of choice especially if there are clinical or ultrasound signs of cerebrovascular circulation compromise. $^{6}$ Yet, even in these cases, angiography is by no means always pathognomonic. ${ }^{28} 293149$ The advent of magnetic resonance angiography allows evaluation of luminal caliper non-invasively as well.

However, if the dissection occurs in the subadventitial layer, considerable wall expansion into the carotid space and displacement of the adjacent parapharyngeal space may occur (figs $2 \mathrm{~b}$ and $4 \mathrm{~b}$ ) The resulting haematoma can compress adjacent structures such as the lower cranial nerves (fig 3 ) without causing relevant vessel narrowing. These cases may not be detected by angiography. Not only can no vessel anomaly be seen, but also the clinical picture with isolated cranial nerve palsies is not even considered an indication for angiography. The question therefore arises whether the reported prevalence of subintimal dissection ${ }^{134}$ is merely a consequence of patient selection and the diagnostic method used, since angiography seems an inadequate method to detect subadventitial dissection.

The reported cases raise questions about the significance of aneurysms and tortuosity found on angiography both for establishing the diagnosis and for looking for an underlying arteriopathy.

Aneurysms are reported on angiography in up to $33 \%$ of patients with ICA dissection. ${ }^{31133}$ We have observed three patients with an aneurysm among 27 patients with ICA dissection (11\%): two had small pouches (one of them patient 1) and one (patient 2) had a saccular aneurysm. It is often impossible to determine whether the (saccular) aneurysms were present as congenital malformations before dissection occurred or whether they are the result of a persistent communication between the dissection cavity and the regular lumen of the artery..$^{1527} 28$

Aneurysms of the extracranial ICA segment are sometimes associated with FMD. ${ }^{50}$ FMD in ICA dissection has been reported in as many as $22 \% .^{3}$ However, FMD cannot be considered the main aetiology of ICA dissection. The sex ratios observed in FMD and ICA dissection strongly argue against that: FMD affects up to $80 \%$ women, ${ }^{50}$ and in the present review series $86 \%$ of patients with 
ICA dissection were men. In addition, intracranial aneurysms occur frequently with FMD, ${ }^{50}$ but only exceptionally with ICA dissection.

Tortuosity, next to FMD, is the second most common arterial wall anomaly cited to make a vessel predisposed for dissection. ${ }^{34251}$ In our review (table 1) $10(38 \%)$ of 26 patients whose angiograms could be judged had some degree of tortuosity. Seven (27\%) had a kinking or coiling. According to large series of consecutive, selected carotid arteriograms slight tortuosity is present in $11 \%$ to $31 \%$, but extreme tortuosity (kinking and coiling) in only $3 \%$ to $12 \% .{ }^{45}$ Tortuosity seems to be more frequent in those patients with dissection who have aneurysm formation. Among the 10 patients with tortuosity we found seven with aneurysms $(70 \%)$, whereas the 16 patients without tortuosity had only five aneurysms (31\%). Whether extreme tortuosity alone, not associated with atherosclerosis or dissection, can cause cerebral ischaemia or lower cranial nerve compression is a matter of debate. ${ }^{45}$

Application of MRI and a large index of suspicion may clarify several of the unsettled issues. MRI is the only non-invasive technique to demonstrate mural haematoma and to show its longitudinal extension (fig 2 a) and the degree of wall expansion (fig $2 \mathrm{~b}$ and 4 b). ${ }^{24}$ 26-31 49 Newer techniques such as chemical shift imaging (fat suppression) (fig 4 bl, b2) make MRI more sensitive to even small arterial dissections. ${ }^{49}$ MRI additionally gives information about surrounding tissues. The information provided by MRI at present is complementary to that of angiography.

In conclusion, carotid dissection should be considered in isolated or combined lower cranial nerve palsies, especially if associated with ipsilateral neck pain, headache, and Horner's syndrome. Descriptive terms like "carotidynia", Raeder's syndrome, "migraine with miosis", and all the cranial nerve syndromes with famous eponyms ${ }^{5}$ should be avoided in favour of a causal diagnosis. Today, MRI provides a sensitive non-invasive method for the diagnosis of ICA dissection if performed within the first weeks.

1 Hart RG, Easton JD. Dissection and trauma of cervicocerebral arteries. In: Barnett HJM, ed. Stroke pathophysiology, diagnosis and management. New York: Churchill ology, diagnosis and manage

2 Mokri B, Sundt TM, Houser OW, Piepgras DG Spontaneous dissection of the cervical internal carotid Spontaneous dissection of the cervica
artery. Ann Neurol 1986;19:126-38.

3 Sellier N, Chiras J, Benhamou M, Bories J. Dissections spontanées de la carotide interne. Aspects cliniques radiologiques et évolutifs. A propos de 46 cas. $\mathscr{f}$ Neuroradiol 1983;10:243-59.

4 Hart RG, Easton JD. Dissection of cervical and cerebral arteries. Neurol Clin 1983;1:155-82.

5 Tanaka $M$, Isaka $K$, Morimatsu M, Hirai S. Jugular foramen syndrome. Neurology 1983;32:119-20.

6 Sturzenegger $M$. Ultrasound findings in spontaneous carotid artery dissection. The value of duplex sonography. Arch Neurol 1991;48:1057-63.

7 Silcox LE, Updegrove RA. Extracranial aneurysm of the internal carotid artery. Arch Otolaryngol 1959;69. 329-33.

8 Fisher CM, Ojemann RG, Roberson GH. Spontaneous dissection of cervicocerebral arteries. Can $\mathcal{f}$ Neurol Sci 1978;5:9-19.
9 Maitland CH, Black J, Smith W. Abducens nerve palsy due to spontaneous dissection of the internal carotid artery. Arch Neurol 1983;40:448-9.

10 Francis KR, Williams DP, Troost BT. Facial numbness and dysesthesia, new features of carotid artery dissection. Arch Neurol 1987;44:345-6.

11 Houser WO, Mokri B, Sundt TM, Baker HL, Reese DF. Spontaneous cervical cephalic arterial dissection and its residuum: Angiographic spectrum. AfNR 1984;5: residu 34

12 Guthier G, Rohr J, Wildi E, Megret M. L'hématome disséquant spontané de l'artére carotide interne. Arch Suisses Neurol Psychiatr 1985;136:53-74

13 Labauge R, Thevenet A, Gros C, Vlahovitch B, Peguret $C$, Frèrebeau C. Les anévrysmes due segment exocrânien de l' axe carotidien et leur traitement chirurgical. A propos de 13 observations personnelles. Rev Neurol 1971;124:512-25.

14 Kramer W. Hyperplasie fibromusculaire et anévrysme extracrânien de la carotide interne avec syndrome parapharyngien typique. Rev Neurol 1969;120:239-44.

15 Gros C, Vlahovitch B, Labauge R, Thevenet A, Kuhner $\mathrm{A}$, Frèrebeau $\mathrm{Ph}$. Les anévrysmes extra-crâniens de la carotide interne. Neuro-chirurgie 1970;16:367-82.

16 Cohen DN, Zakov ZN, Salanga VD, Dohn DF. Raeder's paratrigeminal syndrome. Am $f$ Ophthalmol 1975; 79:1044-9.

17 Barbizet J, Degos J-D, Lamotte J, Baulac M. Dissection spontanée de la carotide interne. Ann Méd Interne 1978;129:73-6.

18 Bradac GB, Kaernbach A, Bolk-Weischedel D, Finck GA Spontaneous dissecting aneurysm of cervical cerebral arteries. Neuroradiology 1981;21:149-54.

19 Goodman JM, Zink WL, Cooper DF. Hemilingual paralysis caused by spontaneous carotid artery dissection. Arch Neurol 1983;40:653-4.

20 Hommel M, Pollak P, Gaio JM, Pellat J, Perret J, Chateau R. Paralysies du nerf grand hypoglosse par deux anévrysmes et un anévrysme disséquant de l'artère anevrysmes et un anevrysme disséquant de

21 Mokri B, Piepgras DG, Wiebers DO, Houser OW. Familial occurrence of spontaneous dissection of the internal carotid artery. Stroke 1987;18:246-51.

22 Benrabah R, Bousser MG, Cabanis EA, Lopez A, Moreau J. Syndrome de Claude-Bernard-Horner douloureux revelateur d'une dissection spontanée de l'artère carotide interne. Interet du bilan ultrasonique cervical. 1988;88:763-8.

23 Vighetto A, Lisovoski F, Revol A, Trillet M, Aimrad G. Internal carotid artery dissection and ipsilateral hypoglossal nerve palsy. I Neurol Neurosurg Psychiatry 1990;53:530-1.

24 Goldberg HI, Grossmann RI, Gomory JM, Ashbury AK, Bilaniuk LT, Zimmermann RA. Cervical internal Bilaniuk LT, Zimmermann RA. Cervical internal MRI. Radiology 1986;158:157-61.

25 Hess DC, Sehti KD, Nichols FT. Carotid dissection: a new false localising sign. $\mathcal{F}$ Neurol Neurosurg Psychiatry 1990;53:804-5

26 Lieschke GJ, Davies S, Tress BM, Ebeling P. Spontaneous internal carotid artery dissection presenting as hypoglossal nerve palsy. Stroke 1988;19:1151-5.

27 Waespe W, Niesper J, Imhof HG, Valavanis A. Lower cranial nerve palsies due to internal carotid artery dissection. Stroke 1988;19:1561-4

28 Bradac GB, Riva A, Stura G, Doriguzz C. Dissection spontanée de la carotide interne avec paralysie du XII. $\mathcal{F}$ Neuroradiol 1989;16:197-202.

29 Dal Pozzo G, Mascalchi M, Fonda C, Cadelo M, Ronchi $O$, Inzitari D. Lower cranial nerve palsy due to dissection of the internal carotid artery: CT and MR imaging. tion of the internal carotid artery: CT

30 Vernay D, Deffond D, Durif F, Georget AM, Dordain G. Paralysie du XII au cours d'une dissection carotidienne cervicale haute. Presse Med 1989;18:985-6.

31 Panisset M, Eidelman BH. Multiple cranial neuropathy as a feature of internal carotid artery dissection. Stroke 1990;21:141-7.

32 Bogousslavsky J, Despland P-A, Regli F. Spontaneous carotid dissection with acute stroke. Arch Neurol 1987;44:137-40.

33 Steinke W. Aulich A, Hennerici M. Diagnose und Verlauf von Carotisdissektionen. DMW 1989;114:1869-75.

34 De Bray JM, Leftheriotis G, Causeret H, Pasquier JL, Saumet JL. Les dissections carotidiennes. Etude de 28 cas. Fournal des Maladies Vasculaires 1990;15:321-5.

35 Hennerici M, Steinke W, Rautenberg W. High-resistance Doppler flow pattern in extracranial carotid dissection. Doppler flow pattern in extrac
Arch Neurol 1989;46:670-2.

36 De Bray JM, Dubas F, Joseph PA, Causeret H, Pasquier JP, Emile E. Etude ultrasonique de 22 dissections carotidiennes. Rev Neurol 1989;145:702-9.

37 Biller J, Hingtgen WL, Adams HP, Smoker WRK, Godersky JC, Toffol GJ. Cervicocephalic arterial dissections: a ten-year experience. Arch Neurol 1986;43: 1234-8.

38 Pozzati E, Giuliani G, Acciarri N, Nuzzo G. Long-term follow-up of occlusive cervical carotid dissection. Stroke 1990;21:528-31.

39 Rosat P, Deramond H, Grunewald P, Le Gars D, Galibert P. L'anévrysme disséquant non traumatique de la carotide interne cervicale. Conduite a tenir. Neurochirurgie 1981;27:133-7.

40 Müllges W, Ringelstein EB, Weiller C, Leibold M, 
Brückmann H. Dissektionen der A. carotis interna neue diagnostische und pathogenetische Aspekte. Fortschr Neurol Psychiat 1991;59:12-24.

41 Kaps M, Dorndorf W, Damian MS, Agnoli L. Intracranial hemodynamics in patients with spontaneous carotid dissection. Eur Arch Psychiatr Neurol Sci 1990;239:246-56.

42 Luken MG, Ascherl GF, Correll JW, Hilal SH Spontaneous dissecting aneurysms of the extracranial

43 Marx A, Messing B, Storch B, Busse O. Spontane Dissektionen hirnversorgender Arterien. Nervenarzt 1987;58:8-18

44 Tommasi-Davenas C, Vighetto A, Confavreux C, Aimard G. Causes des paralysies du nerf grand hypoglosse. A propos de 32 cas. La Presse Médicale 1990;19:864-8.

45 Weibel J, Fields WS. Tortuosity, coiling, and kinking of the internal carotid artery. Neurology $1965 ; 15: 7-18$ and 462-8.

46 Lapresle J, Lasjaunias P. Cranial nerve ischaemic arterial syndromes. A review. Brain 1986;109:207-15.

47 Lasjaunias P, Doyon D. L'artere pharygienne ascendante dans la vascularisation des derniéres paires craniennes (IX, X, XI, XII). $\mathcal{F}$ Neuroradiol 1978;5:287-301.

48 Croft RJ, Ellam LD, Harrison MJG. Accuracy of carotid angiography in the assessment of atheroma of the interangiography in the assessment of atheroma

49 Pacini R, Simon J, Ketonen L, Kido D, Kieburtz K. Chemical-shift imaging of a spontaneous internal carotid artery dissection: case report. AfNR 1991;12:360-2.

50 Mettinger KL, Ericson K. Fibromuscular dysplasia and the brain. Stroke 1982;13:46-58.

51 Hart RG, Easton JD. Dissections. Stroke 1985;16:925-7. 